\title{
Exploring the Factors of Foreign Language Anxiety Among Chinese Undergraduate English Majors and Non-English Majors
}

\author{
Mehwish Naudhani ${ }^{1,2}$, Zhijie $\mathrm{Wu}^{1}$ \& Sehrish Naudhani ${ }^{2}$ \\ ${ }^{1}$ School of Foreign Studies, Nanjing University of Science and Technology, Nanjing, China \\ ${ }^{2}$ Department of English, Baluchistan University of Information Technology, Engineering and Management \\ Sciences, Quetta 87300, Pakistan \\ Correspondence: Zhijie Wu, School of Foreign Studies, Nanjing University of Science and Technology, Nanjing, \\ China.
}

Received: March 25, 2018 Accepted: May 19, 2018 Online Published: June 9, 2018

doi:10.5539/ijel.v8n5p142 URL: https://doi.org/10.5539/ijel.v8n5p142

\begin{abstract}
The study aims to examine three factors of foreign language anxiety i.e. speaking anxiety, foreign language classroom anxiety and teacher-generated anxiety, among Chinese English majors and non-English majors. The data were analysed to find out which of these factors invoke more anxiety. Research data collection was done via Foreign Language Anxiety Scale. A total number of subjects are 101, including 51 English majors and 50 non-English majors, with Chinese as their mother-tongue and learning English as a second language at university. The results revealed that English majors feel the middle level of foreign language speaking and classroom anxiety while Non-English majors experience high level of foreign language speaking and classroom anxiety. Moreover, both groups felt more anxious when they spoke to the teacher. Keeping in view the results of the study, some follow-up studies are recommended.
\end{abstract}

Keywords: Language anxiety, speaking anxiety, foreign language classroom anxiety, teacher-generated anxiety, Chinese English majors, non-English majors

\section{Introduction}

The English language is considered as one of the leading International Languages in the 21st Century, a number of its local speakers is less than the number of its users as a second or foreign language (McKay, 2002). English is the most demanded language of the current century, it has gained the status of "a language for communication internationally". Mehmoodzadeh (2012, p. 466) describes "The ever-growing need for a good communication skill in the English Language has created a worldwide demand for achieving a good command on English among its non-native speakers around the globe".

Learners around the globe share common features. Whenever they learn new skills, naturally they may feel shy in applying them publically. Learners do not like to commit errors in front of their classmates. Anxiety is a common factor in learning a new language (Landström, 2015). Wu (2010) and Zheng (2008) argue that it is essential for learners to overcome language anxiety because it is a key hindrance to foreign language learning. For individuals who have a good command of their native language, when they are asked to use their second language they feel themselves reduced to a childlike state (Horwitz, Horwitz, \& Cope, 1986). Additionally, learners of a foreign language often feel threatened in their self-perception in the language class (Pappamihiel, 2002). Language anxiety impacts learner's level of accomplishment in the process of learning (Dordinejad \& Ahmadabad, 2014).

Since 1970s linguists have been working on the phenomenon of language anxiety and its causes. Disregarding promotion in teaching methodologies, learners still suffer from foreign language classroom anxiety (Lui, 2006). The main objective of this survey is to examine three factors of foreign language anxiety among Chinese undergraduate English majors and non-English majors i.e. speaking anxiety, foreign language classroom anxiety and teacher-based anxiety and to find out which of these factors raise more anxiety.

\section{Foreign Language Anxiety}

Horwitz et al. (1986, p. 130) described foreign language anxiety as "A distinct complex of self-perception, beliefs, feelings, and behaviours related to classroom language learning arising from the uniqueness of the 
language learning process". The phenomenon of anxiety is a composite and multifaceted (Young, 1991). According to MacIntyre \& Gardner (1994, p. 284) language anxiety is "The feeling of tension and apprehension specifically associated with second language contexts, including speaking, listening, and learning". However, all of these factors stop the learners from effective performance (Hashemi \& Abbasi, 2013). In the latest studies, the linguists have accepted that anxiety in learning a language is a distinctive anxiety that is independent of other general kinds of anxiety (Horwitz et al., 1986). Though anxiety in language learning is occasionally measured as facilitative if it is minor, generally the overall negative consequence of anxiety in second language acquisition is worth noticing.

\subsection{Factors of Language Anxiety}

Horwitz, Horwitz \& Cope (1986) suggested three causes of foreign language anxiety, i.e. Communication apprehension, test anxiety and fear of negative evaluation. Zhang and Zhong (2012, p. 27) considered factors of foreign language anxiety as "learner-induced, classroom-related, skill-specific, and some society-imposed depending on different contexts".

Hesitation in speaking is one of the normal issues that every foreign language learners experience (Hamzah \& Asokan, 2016). Learners of English as a foreign language are typically submissive and hesitant to speak; they often experience issues in communicating and imparting in speaking activities during language classes (Gan, 2012). MacIntyre and Gardner (1991) view that the basic constituents of foreign language anxiety are communication apprehension and fear of negative evaluation. When learners are asked to speak in the classroom, communication apprehension occurs (Zhanibek, 2001). Moreover, "learners whose personalities tend to fear negative evaluation seem to be strong candidates for experiencing anxiety in foreign language classrooms" (Kitano, 2001, p. 550). Anxiety in learning a foreign language is free from first language learning incapacities and ought to be seen as a critical variable that blocks language learning all by itself (Horwitz, 2001).

Language learners are always fascinated by the language style and level that native speakers have and it consequently results in language anxiety since they failed to fulfil the selective necessities (Zhang \& Zhong, 2012). Students make language principles in which they have many beliefs and expectations but they fail to learn like natives and this results in language anxiety. In other words, the formulated standards that are laid by learners are hard to achieve in and out of language classes and results in anxiety. Students constantly fear that their language skills, principally speaking skills, are not as good as their classmates' language skills are (Young, 1991). Speaking abilities are the primary concern that learners reliably compare with their friends, tutors and native speakers. If learners want to learn a language like native speakers, language teachers and audiovisual aids can be useful for learning a foreign language (Kitano, 2001).

Elaldi (2016, p. 221) asserts that "Fear of testing is another source of anxiety stemming from the classroom environment, where learners are constantly being evaluated". Students mark incorrect response in the tests due to anxiety (Conway, 2007). Young (1991, p. 429) states that "In language testing, the greater degree of students' evaluation and the more unfamiliar and ambiguous the test tasks and formats, the more the learners' anxiety is produced". Foreign language learners became anxious because they lack confidence (Dalkalic, 2001). Anxious learners try to avoid participation in the classroom (Gregerson \& Horwitz, 2002). Language learning tactics are most important aspects of foreign language learning (Skehan, 1989). Proper learning systems result in enhanced capability and more noteworthy self-assurance in many cases (Chamot \& Kupper, 1989; Wenden \& Rubin, 1987; O’Malley \& Chamot, 1990; Cohen, 1990; Oxford \& Crookall, 1989). Hashemi and Abbasi (2013) argue that friendly and agreeable classroom conditions can overcome language anxiety. According to them strict teaching methodology in the language class is the primary cause of tension and anxiety since strict instructions in language class stop correspondence in objective language.

To sort out the reasons of language anxiety, Horwitrz et al. (1986) propose the Foreign Language Classroom Anxiety Scale (FLCAS). To check the reliability of their FLCAS they selected 75 students from American University with English as their mother tongue and Spanish as second or foreign language. The results revealed that learners were facing a significant level of foreign language anxiety. The learners with a high level of anxiety were reluctant to speak in the language classes and feel more anxious during language class rather than other course classes. In addition, the study also supported researcher's opinions "foreign language anxiety is a distinct complex of self-perception, beliefs, feelings, and behaviours related to classroom language learning arising from the uniqueness of the language learning process" (Horwitz et al., 1986, p. 130). Furthermore, Young (1986), MacIntyre and Gardner (1989), Aida (1994) and Kitano (2001) also noted that language anxiety affects the performance of learners. Learners suffering from high level of language anxiety tend to achieve lower scores as compared to less anxious learners. Moreover, Liu (2006) examined Chinese undergraduate non-English majors 
at three different proficiency levels, revealed that out of 147 learners, more than one-third learners seemed to be anxious in a foreign language class. The learners reported that they became more anxious while speaking to the instructor.

China has the largest number of English as a foreign language learners around the globe. The importance of English language is growing day by day in mainland of China, especially speaking and writing skills are more focused but learners of English language still have little interaction with the language and its native speakers (Liu \& Braine, 2005). Many Chinese students feel anxious when they speak English; still, this area is not much studied (Wang \& Ding, 2001; Chen, 2002; Hu, 2003). In order to address this issue, the current study focuses on three factors of English language anxiety among 101 undergraduate Chinese-speaking English language learners i.e. speaking anxiety, foreign language classroom anxiety and teacher-based anxiety. The collection of data was carried out on 51 English-major undergraduates and 50 English-non-major undergraduates. More specifically, students' responses are analysed through Foreign Language Anxiety Scale by Horwitz et al. (1986) in order to answer the given questions.

1. What is the extent of effects of English speaking, foreign language classroom and teacher-generated anxiety on students' performance in the English language class?

2. The greater amount of anxiety among students is invoked by which one of the mentioned factors?

3. Is there any difference between English major and non-English major with respect to the degree of English language anxiety?

\section{Methodology}

\subsection{Research Design}

The Survey model, one of the descriptive research designs, was used to carry out the present study. According to Gay and Mills (2011:175) "A survey is an instrument to collect data that describes one or more characteristics of a specific population".

\subsection{Participants}

The study was comprised of 101 Chinese-born undergraduate students. Among a total number of respondents, 51 are second-year English majors and 50 are second-year non-English majors. All of these participants were learners of English as a foreign language.

\subsection{Instruments}

Foreign language classroom anxiety scale- (FLCAS) developed by Hoewitz et al. (1986), was adopted for data collection. The instrument is featured to measure factors of foreign language anxiety among the students in the classroom. The FLCAS is composed of a 5-point Likert scale with 33 statements, extending from "strongly agree" to "strongly disagree". "Strongly agree" indicates the highest level of foreign language anxiety and "strongly disagree" shows the lowest level of foreign language anxiety that learners feel in the classroom (Horwitz, 2008). The questionnaire in this research contains 19 items. All the 19 investigated three factors of foreign language anxiety i.e. speaking anxiety, foreign language classroom anxiety and teacher-generated anxiety, among Chinese English majors and non-English majors.

\subsection{Data Collection Procedure}

The data collection was carried out by distributing two sets of questionnaires among both groups i.e. English majors and non-English majors. Before distribution of questionnaires participants were informed about the purpose of the study and they were assured that their names would not be mentioned anywhere in the study. Among the two sets of questionnaires, one set of 51 questionnaires were distributed among the Chinese English majors and the second set of 50 questionnaires were distributed among Chinese non-English majors. There was no time limitation for the participants for filling in the questionnaire. To increase the reliability of answers, the authors helped the students comprehend the items.

\subsection{Data Analysing Method}

The Statistical package for the social sciences (SPSS) was adopted to perform the descriptive statistics. The data were analysed by calculating the arithmetic mean, standard deviation and independent samples t-tests, of responses to sort out three factors of English language anxiety (speaking anxiety, foreign language classroom anxiety and teacher-generated) among both groups, i.e. English majors and non-English majors and to find out which factor invoke more anxiety among students. 


\section{Data Analysis}

The Data were collected from Chinese undergraduate English majors and non-English majors. Mostly the Chinese respondents like to choose options "neutral", although they are quite sure that they really want to select "Agree/strongly agree" or "Disagree/strongly disagree" (Yang \& Lu, 2008; He, 2011). Among both groups, some participants randomly remained neutral at few statements. Nevertheless, this did not bring any difficulty in data analysis. For the data analysis, questionnaire comprised of 5 points Likert scale is used. Usually the options "agree" and "strongly agree" are calculated collectively as "agree", and "disagree" and "strongly disagree" as "disagree" for more clarity (e.g., He, 2011; Peacock, 2010; Horwitz et al., 1986). However, a five-point Likert scale is used during the process of data collection because it is mostly used by the researcher for surveys, evaluating attitudes, perspectives, and views. If a three-point scale is adopted, even more number of respondents will probably select "neutral" (DeVellis, 1991).

To answer the research questions, the FLCAS has been divided into three portions i.e., foreign language speaking anxiety, foreign language classroom anxiety and teacher-generated anxiety. The results and interpretation of both variables i.e., Chinese English majors and Chinese non-English majors are given in the following tables:

Table 1. Mean score for speaking anxiety among Chinese English majors and non-English majors

\begin{tabular}{llll}
\hline Statements & Variables & Mean & Std.D \\
\hline I never feel quite sure of myself when I am speaking in my foreign & Chinese English Majors & 3.666 & 1.227 \\
language class & Chinese non-English Majors & 3.880 & 0.982 \\
I start to panic when I have to speak without preparation in a language & Chinese English Majors & 3.392 & 1.217 \\
class. & Chinese non-English Majors & 3.680 & 0.935 \\
I always feel that the other students speak the foreign language better & Chinese English Majors & 3.470 & 1.238 \\
than I do & Chinese non-English Majors & 3.820 & 1.082 \\
I feel very self-conscious about speaking the foreign language in front of & Chinese English Majors & 3.529 & 1.083 \\
other students & Chinese non-English Majors & 3.740 & 1.046 \\
I get nervous and confused when I am speaking in my language class & Chinese English Majors & 3.588 & 1.134 \\
& Chinese non-English Majors & 3.640 & 1.102 \\
I feel overwhelmed by the number of rules you have to learn to speak a & Chinese English Majors & 3.529 & 1.361 \\
foreign language & Chinese non-English Majors & 3.800 & 1.195 \\
I am afraid that the other students will laugh at me when I speak the & Chinese English Majors & 3.588 & 1.202 \\
foreign language & Chinese non-English Majors & 3.640 & 1.138 \\
I keep thinking that the other students are better at languages than I am & Chinese English Majors & 3.313 & 1.104 \\
& Chinese non-English Majors & 3.360 \\
\hline
\end{tabular}

In the above table 1, the 8 items from FLCAS represents speaking anxiety between two groups, i.e. Chinese English majors and non-English majors. The data in the above table shows that English major learners feel a moderate level of foreign language speaking anxiety $(\mathrm{M}=3.666, \mathrm{SD}=1.227)$, whereas Non-English major learners experience a higher level of foreign language speaking anxiety $(\mathrm{M}=3.880, \mathrm{SD}=0.982)$. Majority of the learners in both groups reported the existence of foreign language speaking anxiety in themselves (see table 1) and they showed their agreement that because of lack of confidence they feel anxious while speaking in the English language. These outcomes are alike to the opinion by Horwitz et al. (1986, p. 130) "seeking refuge in the last row in an effort to avoid the humiliation or embarrassment of being called on to speak". Language anxiety is a major factor that impacts the capabilities of foreign language learners. It has a strong relationship with communication apprehension. As Horwitz et al. (1986) stated that in communication apprehension, learners not only face difficulties in speaking but also in understanding what others say. Usually, anxiety leads learners to discouragement, they always try to avoid participation in classroom activities, stop trusting their abilities, and at the end stop putting efforts in learning a language. This affects their achievements, and anxious students are mostly left behind in achieving good grades in the language class. 
Table 2. Independent samples t-test result of speaking anxiety

\begin{tabular}{llllllll}
\hline & Groups & N & Mean & Std. Deviation & T & df & P-value \\
\hline $\begin{array}{l}\text { Speaking } \\
\text { Anxiety }\end{array}$ & $\begin{array}{l}\text { Chinese English } \\
\text { Majors }\end{array}$ & 3.509 & 0.114 & -2.659 & 14 & 0.019 \\
& $\begin{array}{l}\text { Chinese Non-English } \\
\text { Majors }\end{array}$ & 8 & 3.695 & 0.160 & & & \\
& & & & & & \\
\hline
\end{tabular}

The independent $\mathrm{t}$-test result in the above table reveals that there is a significant difference between Chinese English Majors $(\mathrm{M}=3.509, \mathrm{SD}=0.114)$ and Chinese Non-English Majors $(\mathrm{M}=3.695, \mathrm{SD}=0.160) ; \mathrm{t}=-2.659$ and P-value (0.019). It is noted that P-value (0.019) is smaller than $\alpha=0.05$, so it shows that both groups feel anxious while speaking in the foreign language.

Table 3. Mean score for foreign language classroom anxiety among Chinese English majors and non-English majors

\begin{tabular}{|c|c|c|c|}
\hline Statements & Variables & Mean & Std.D \\
\hline \multirow[t]{2}{*}{ I tremble when I know that I'm going to be called on in language class } & Chinese English Majors & 3.215 & 1.188 \\
\hline & Chinese non-English Majors & 3.360 & 1.083 \\
\hline \multirow[t]{2}{*}{ I worry about the consequences of failing my foreign language class } & Chinese English Majors & 3.274 & 1.114 \\
\hline & Chinese non-English Majors & 3.680 & 1.185 \\
\hline \multirow[t]{2}{*}{ In language class, I can get so nervous I forget things I know } & Chinese English Majors & 3.019 & 1.029 \\
\hline & Chinese non-English Majors & 3.580 & 1.031 \\
\hline \multirow[t]{2}{*}{ Even if I am well prepared for a language class, I feel anxious about it } & Chinese English Majors & 3.235 & 1.176 \\
\hline & Chinese non-English Majors & 3.660 & 1.022 \\
\hline \multirow[t]{2}{*}{ I can feel my heart pounding when I'm going to be called on in language class } & Chinese English Majors & 3.058 & 1.138 \\
\hline & Chinese non-English Majors & 3.320 & 0.978 \\
\hline \multirow[t]{2}{*}{ Language class moves so quickly I worry about getting left behind } & Chinese English Majors & 2.745 & 1.246 \\
\hline & Chinese non-English Majors & 3.540 & 1.110 \\
\hline \multirow[t]{2}{*}{ I feel more tense and nervous in my language class than in my other classes } & Chinese English Majors & 2.902 & 1.187 \\
\hline & Chinese non-English Majors & 3.420 & 1.126 \\
\hline
\end{tabular}

A notable difference in anxiety level of foreign language classroom is found among Chinese English major learners $(\mathrm{M}=3.274, \mathrm{SD}=1.114)$ and non-English major learners $(\mathrm{M}=3.680, \mathrm{SSD}=1.185)$. In the present study, non-English major learners are found to suffer a high level of language classroom anxiety than English major learners (see table 2). The above results reveal that non-English major feel more anxious in the foreign language classroom as compared to English major learners. Being a part of the classroom might suggest that one is going to be compared with other class fellows. This correlation may bring about learners anxious and they stop trusting in their abilities. A spiral of negative sentiments associated with English may arouse, producing more depression and anxiety (Landström, 2015). In the conditions where nervousness makes students tremble, worry about bad outcomes so much that they forget the things they know, students gradually lose their interest in language classes.

Table 4. Independent samples t-test result of foreign language classroom anxiety

\begin{tabular}{lllllll}
\hline & Groups & N & Mean & Std. Deviation & T & df \\
\hline & $\begin{array}{l}\text { Chinese English } \\
\text { Foreign } \quad \text { Language }\end{array}$ & 7 & 3.064 & 0.194 & -4.869 & 12 \\
Majors & $\begin{array}{l}\text { Passroom Anxiety } \\
\text { Chinese Non-English } \\
\text { Majors }\end{array}$ & 7 & 3.508 & 0.143 & \\
\hline
\end{tabular}

The independent t-test result shows that there is a significant difference between Chinese English Majors $(\mathrm{M}=3.064, \mathrm{SD}=0.194)$ and Chinese Non-English Majors $(\mathrm{M}=3.508, \mathrm{SD}=0.143) ; \mathrm{t}=-4.869$ and $\mathrm{P}$-values $(0.00)$. As P-value (0.00) is smaller than $\alpha=0.05$, so it shows that there is a difference between anxiety levels among two groups. Non-English majors feel more anxious in the foreign language classroom then English majors. 
Table 5. Mean score for teacher generated anxiety among Chinese English majors and non-English majors

\begin{tabular}{llll}
\hline Statements & Variables & Mean & SD \\
\hline I get nervous when the English teacher asks questions which I haven't & Chinese English Majors & 3.490 & 1.120 \\
prepared in advance & Chinese non-English Majors & 3.560 & 1.052 \\
I get upset when I don't understand what the teacher is correcting & Chinese English Majors & 3.451 & 1.006 \\
& Chinese non-English Majors & 3.340 & 1.080 \\
I get nervous when I don't understand every word the English teacher says & Chinese English Majors & 3.333 & 1.089 \\
& Chinese non-English Majors & 3.340 & 1.238 \\
I am afraid that my language teacher is ready to correct every mistake I & Chinese English Majors & 3.392 & 0.981 \\
make & Chinese non-English Majors & 3.500 & 1.015 \\
\hline
\end{tabular}

The findings in the above table explored that a considerable number of learners among both groups suffer from teacher-generated anxiety. It is clear from the results that instructor can be the cause of anxiety among learners. Students hesitate to show their English language aptitudes in fright of obtaining low marks, which could impact them in their future life. Keeping in view learner's anxious attitude towards language learning, the teacher should work towards making such a classroom domain in which slip-ups and mistakes are not seen as something to be humiliated about but instead as a stage towards learning process.

Table 6. Independent samples t-test result of teacher-generated anxiety

\begin{tabular}{|c|c|c|c|c|c|c|c|c|}
\hline & & Groups & $\mathbf{N}$ & Mean & Std. Deviation & $\mathbf{T}$ & df & P-value \\
\hline & & Chinese English & 4 & 3.416 & 0.069 & -0.278 & 6 & 0.790 \\
\hline Foreign & Language & Majors & & & & & & \\
\hline Anxiety & & $\begin{array}{l}\text { Chinese Non-English } \\
\text { Majors }\end{array}$ & 4 & 3.435 & 0.112 & & & \\
\hline
\end{tabular}

The independent t-test result in the above table reveals that there is no significant difference between Chinese English Majors $(\mathrm{M}=3.416, \mathrm{SD}=0.069)$ and Chinese Non-English Majors $(\mathrm{M}=3.435, \mathrm{SD}=0.112) ; \mathrm{t}=-0.278$ and P-values 0.790 . so, it shows that both groups feel anxious while speaking in the foreign language classroom and they are also very much anxious about a foreign language teacher.

\section{Discussion}

The findings of the present survey show that majority of the university students in the mainland China who took part in filling questionnaire suffer from high level of foreign language anxiety i.e. Speaking anxiety, foreign language classroom anxiety and teacher-generated anxiety. The differences in the level of foreign language anxiety between the two groups i.e. English majors and non-English majors achieved the level of statistical implication. The English major learners appeared less anxious about a foreign language than non-English major learners. The researcher divided 19 items taken from FLCAS scale into three sets i.e. speaking anxiety, foreign language classroom anxiety and teacher-generated anxiety. Among these three factors, the major difference in the responses related to foreign language classroom anxiety was found. English majors seemed to be less anxious during the language class than non-English majors. It might be the reason that English majors attend more classes in a foreign language than non-English majors. In addition, a slight difference in the level of anxiety related to foreign language speaking and language teacher was found.

The results demonstrate that Chinese students at university level face a high level of foreign language speaking anxiety because of different variables, for example, communication apprehension, fear of negative evolution, testing, teacher's corrections etc. As MacIntyre and Gardner (1991) describe, "the basic components of foreign language anxiety are communication apprehension and fear of negative evaluation". Zhang and Zhong (2012, p. 27) also classified factors of foreign language anxiety as "learner-induced, classroom-related, skill-specific, and some society-imposed depending on different contexts". Like many previous studies on foreign language anxiety, learners were found highly anxious, particularly while speaking in the foreign language and level of teacher-generated anxiety was also high among Chinese English major learners and non-English major learners. These findings are in line with the number of significant studies (i.e. Horwitz et al., 1986; Kitno, 2001; Liu, 2006; Deyuan, 2011; Landström, 2015). However, the existence of foreign language speaking anxiety was found among more than half of the learners in both groups and because of lack of confidence learners feel anxious when they speak in the English language. Language anxiety is a major factor that impacts the capabilities of foreign language learners. It has a strong relationship with communication apprehension. As Horwitz, et al. 
(1986) stated that in communication apprehension, learners not only face difficulties in speaking but also in understanding what others say. This effect their achievements, mostly anxious students left behind in achieving good grads in the language class. Moreover, learners as a part of the classroom are compared with other class fellows. This comparison may cause learners nervous and they gradually lose confidence in their skills. A spiral of negative sentiments associated with English may arouse, producing more depression and anxiety (Landström, 2015). In the circumstances where anxiety arouses the students start trembling, worry about consequences of failure and as a result, they overlook the things they already know. According to von Wörde (200, p. 9), the notion of foreign language anxiety is a part of the fear of negative evaluation and this fear of negative evaluation is a key cause of teacher-based anxiety. Learners are reluctant to demonstrate their English abilities in dread of getting low marks, which may influence them in their upcoming life. Keeping in mind the end goal to decrease anxiety the instructor ought to work towards making such a classroom environment in which mistakes and errors are not seen as something to be embarrassed about but rather as a step towards learning process. Therefore, during language class teacher should be careful while making corrections. Teachers' style of should be deliberate; it should not humiliate students in front of others because teacher's style of instructions plays an important role in making students' confident or cause students to suffer even more.

The results suggest that more efforts are needed to improve teaching methodologies in order to decrease student's foreign language anxiety. Learner's foreign language anxiety is usually ignored by the instructors, teachers think that due to lack of confidence, proficiency and motivation, learners are reluctant to participate in classroom activities. Young (1991, p. 428) states that "Language anxiety in the learner is probably caused when instructors consider their role as a constant error-corrector and "drill sergeant" rather than a "facilitator", when they do not promote group work for fear of losing control of the class, and when they believe teachers should be responsible for most of the talking and teaching". If the instructor provides less chance to the students to speak, gradually they will lose interest in participation, which results in silence on student's part and will drive the instructor to speak more and slowly this situation will indicate more anxiety (Tsui, 1996).

\section{Conclusions}

The results in the present study imply that the majority of the university students in the mainland China suffer from foreign language anxiety. Both groups, i.e. English major and non-English majors, feel anxious while speaking in front of the teacher as well as their peers. They are afraid of losing their face and getting bad results. In other words, students feel that they are unable to understand what teacher is teaching in this way they will speak wrong and teacher will make corrections, consequently, their peers will laugh at them. Student's impractical or inaccurate opinions about learning a language are generally accountable for the cause of anxiety (Zhang \& Zhong, 2012). Furthermore, the teacher's teaching methods and views play an important role to analyse the learner's problems and difficulties they are facing in the process of foreign language learning. Thus, teachers should be aware of their basic role in teaching a foreign language and alter their teaching methodology accordingly. As Zhang and Zhong (2012, p. 31) state that "Once these causes of language anxiety can be thoroughly identified, we may look into the direction for further identifying the effects of anxiety on second language development".

However, the findings of this study may not be enough to provide effective strategies to decrease students' anxiety level. It is necessary to conduct follow-up studies, both qualitative and quantitative with a large number of participants including both English majors and non-English majors from different educational institutions. Moreover, instructors play an important role in decreasing learner's foreign language anxiety, some studies must be conducted on effective teaching methods to reduce foreign language among Chinese students.

\section{References}

Aida, Y. (1994). Examination of Horwitz, Horwitz, and Cope's construct of foreign language anxiety: The case of students of Japanese. The Modern Language Journal, 78(2), 155-168. https://doi.org/10.1111/j.1540-4781.1994.tb02026.x

Chamot, A. U., \& Kupper, L. (1989). Learning strategies in foreign language instruction. Foreign Language Annals, 22(1), 13-22. https://doi.org/10.1111/j.1944-9720.1989.tb03138.x

Chen, H. (2002). College students' English learning anxiety and their coping styles. Unpublished M.A. dissertation, Southwest Normal University, China.

Cohen, A. D. (1990). Language Learning: Insights for Learners, Teachers, and Researchers. New York: Newbury House.

Conway, J. (2007). Anxiety in second language learning; Causes and solutions. Recuperado el, 1 . 
Dalkiliç, N. (2001). The role of foreign language classroom anxiety in English speaking courses. Çukurova Üniversitesi Sosyal Bilimler Enstitüsü Dergisi, 8(8).

DeVellis, R. F. (1991). Scale development: Theory and applications. Newbury Park, CA: Sage.

Dordinejad, F. G., \& Ahmadabad, R. M. (2014). Examination of the relationship between foreign language classroom anxiety and English achievement among male and female Iranian high school students. Int. J. Language Learn. Appl. Linguistics World, 6(4), 446-460.

Elald, S.. (2016). Foreign language anxiety of students studying English Language and Literature: A Sample from Turkey. Educational Research and Reviews, 11(6), 219-228. https://doi.org/10.5897/ERR2015.2507

Gan, Z. (2012). Understanding L2 Speaking Problems: Implications for ESL Curriculum Development in a Teacher Training Institution in Hong Kong. Australian Journal of Teacher Education, 37(1), 43-59. https://dx.doi.org/10.14221/ajte.2012v37n1.4

Gay, L. R., Mills, G. E., \& Airasian, P. W. (2011). Educational research: Competencies for analysis and applications. Pearson Higher Ed.

Gregersen, T., \& Horwitz, E. K. (2002). Language learning and perfectionism: Anxious and non-anxious language learners' reactions to their own oral performance. The Modern Language Journal, 86(4), 562-570. https://doi.org/10.1111/1540-4781.00161

Hamzah, M. H., \& Asokan, T. (2016). The Effect of Participation Instruction on ESL Students' Speaking Skills and Language Anxiety.

Hashemi, M., \& Abbasi, M. (2013). The role of the teacher in alleviating anxiety in language classes. International Research Journal of Applied and Basic Sciences, 4(3), 640-646.

He, D. (2011). Foreign language speaking anxiety: an investigation of non-English majors in mainland China. Doctoral dissertation, City University of Hong Kong.

Horwitz, E. (2001). Language anxiety and achievement. Annual review of applied linguistics, 21, 112-126.

Horwitz, E. K. (2008). Becoming a language teacher: A practical guide to second language learning and teaching. Boston, MA: Allyn and Bacon.

Horwitz, E. K., Horwitz, M. B., \& Cope, J. (1986). Foreign language classroom anxiety. The Modern Language Journal, 70, 125-132. https://doi.org/10.1111/j.1540-4781.1986.tb05256.x

$\mathrm{Hu}, \mathrm{H}$. (2003). The influence of anxiety and self-confidence on English learning. Teaching English in China, 26(1), 36-39.

Kitano, K. (2001). Anxiety in the college Japanese language classroom. The Modern Language Journal, 85(4), 549-566. https://doi.org/10.1111/0026-7902.00125

Landström, P. (2015). Foreign language anxiety among Chinese senior middle school students: A case study.

Liu, M. (2006). Anxiety in Chinese EFL students at different proficiency levels. System, 34(3), 301-316. https://doi.org/10.1016/j.system.2006.04.004

Liu, M. H., \& Braine, G. (2005). Cohesive features in argumentative writing produced by Chinese undergraduates. System, 33(4), 623-636. https://doi.org/10.1016/j.system.2005.02.002

MacIntyre, P. D., \& Gardner, R. C. (1989). Anxiety and second-language learning: Toward a theoretical clarification. Language Learning, 39(2), 251-275. https://doi.org/10.1111/j.1467-1770.1989.tb00423.x

MacIntyre, P. D., \& Gardner, R. C. (1991). Language anxiety: Its relationship to other anxieties and to processing in native and second languages. Language learning, 41(4), 513-534. https://doi.org/10.1111/j.1467-1770.1991.tb00691.x

MacIntyre, P. D., \& Gardner, R. C. (1994). The subtle effects of language anxiety on cognitive processing in the second language. Language Learning, 44(2), 283-305. https://doi.org/10.1111/j.1467-1770.1994.tb01103.x

McKay, S. L. (2002). Teaching English as an international language. Oxford, UK: Oxford University Press.

Mehmoodzadeh, M. (2012). Investigating foreign language speaking anxiety within the EFL learner's inter-language system: The case of Iranian learners. Journal of Language Teaching and Research, 3(3), 466-476.

O'Malley, J. M., \& Chamot, A. U. (1990). Learning strategies in second language acquisition. Cambridge: Cambridge University Press. 
Oxford, R. L., \& Crookall, D. (1989). Research on language learning strategies: methods, findings, and instructional issues. Modern Language Journal, 73, 404-419.

Pappamihiel, N. E. (2002). English as a second language students and English language anxiety: Issues in the mainstream classroom. Research in the Teaching of English, 327-355.

Peacock, M. (2010). Attribution and learning English as a foreign language. ELT Journal, 64(2), 184-193. https://doi.org/10.1093/elt/ccp031

Price, M. L. (1991). The subjective experience of foreign language anxiety: Interviews with highly anxious students. Language anxiety: From theory and research to classroom implications, 101-108.

Skehan, P. (1989). Individual differences in second-language learning. London: Arnold.

Tsui, A. B. (1996). Reticence and anxiety in second language learning. Voices from the language classroom, 145-167.

Von Worde, R. (2003). Students' Perspectives on Foreign Language Anxiety. Inquiry, 8(1), n1.

Wang, Q., \& Ding, X. (2001). Language anxiety among rural middle school students in west China. Journal of Northwest Normal University, 38(5), 68-73.

Wenden, A. (1987). How to be a successful language learner: Insights and prescriptions from L2 learners. In A. Wenden \& J. Rubin (Eds.), Learner Strategies in Language Learning (pp. 103-118). NJ: Englewood Cliffs.

Wu, K. H. (2010). The relationship between language learners' anxiety and learning strategy in the CLT classrooms. International Education Studies, 3(1), 174. https://dx.doi.org/10.5539/ies.v3n1p174

Yang, G., \& Lu, L. (Eds.). (2008). Chinese self: Psychological analysis (Zhongguoren de ziwo: Xinlixue de fenxi). Taipei: National Taiwan University Press (Taida chuban zhongxin).

Young, D. J. (1986). The relationship between anxiety and foreign language oral proficiency ratings. Foreign Language Annals, 19(5), 439-445. https://doi.org/10.1111/j.1944-9720.1986.tb01032.x

Young, D. J. (1991). Creating a Low-Anxiety Classroom Environment: What Does Language Anxiety Research $\begin{array}{lllll}\text { Suggest? The Modern } & \text { Language }\end{array}$ https://doi.org/10.1111/j.1540-4781.1991.tb05378.x

Zhang, R., \& Zhong, J. (2012). The hindrance of doubt: Causes of language anxiety. International Journal of English Linguistics, 2(3), 27. http://dx.doi.org/10.5539/ijel.v2n3p27

Zhanibek, A. (2001). The Relationship between Language Anxiety and Student's Participation in Foreign Language Classes. Doctoral dissertation, Bilkent University.

Zheng, Y. (2008). Anxiety and second/foreign language learning revisited. CJNSE/RCJCÉ, 1(1).

\section{Copyrights}

Copyright for this article is retained by the author, with first publication rights granted to the journal.

This is an open-access article distributed under the terms and conditions of the Creative Commons Attribution license (http://creativecommons.org/licenses/by/4.0/). 